Western University

Scholarship@Western

Aboriginal Policy Research Consortium International (APRCi)

2001

\title{
Aboriginal Living Conditions and Response Paradigms
}

Lester Thompson

University of Queensland

Follow this and additional works at: https://ir.lib.uwo.ca/aprci

Part of the Infrastructure Commons, Policy Design, Analysis, and Evaluation Commons, and the Public Administration Commons

Citation of this paper:

Thompson, Lester, "Aboriginal Living Conditions and Response Paradigms" (2001). Aboriginal Policy Research Consortium International (APRCi). 430.

https://ir.lib.uwo.ca/aprci/430 
This article was downloaded by: [University of Western Ontario]

On: 07 December 2012, At: 07:42

Publisher: Routledge

Informa Ltd Registered in England and Wales Registered Number: 1072954 Registered office: Mortimer House, 37-41 Mortimer Street, London W1T 3J H, UK

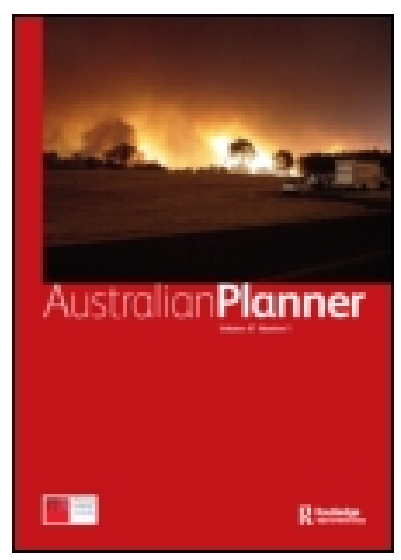

\title{
Australian Planner
}

Publication details, including instructions for authors and subscription information: http:// www. tandfonline.com/loi/ rapl20

\section{ABORIGINAL LIVING CONDITIONS AND RESPONSE PARADIGMS}

\author{
LESTER THOMPSON ${ }^{\text {a b }}$ \\ a School of Human Services, Queensland University of Technology \\ ${ }^{\mathrm{b}}$ Aboriginal Environments Research Centre, University of Queensland \\ Version of record first published: 15 Dec 2010.
}

To cite this article: LESTER THOMPSON (2001): ABORIGINAL LIVING CONDITIONS AND RESPONSE PARADIGMS, Australian Planner, 38:3-4, 151-157

To link to this article: http:// dx. doi.org/ 10.1080/07293682.2001.9657960

\section{PLEASE SCROLL DOWN FOR ARTICLE}

Full terms and conditions of use: http://www.tandfonline.com/page/terms-and-conditions

This article may be used for research, teaching, and private study purposes. Any substantial or systematic reproduction, redistribution, reselling, loan, sub-licensing, systematic supply, or distribution in any form to anyone is expressly forbidden.

The publisher does not give any warranty express or implied or make any representation that the contents will be complete or accurate or up to date. The accuracy of any instructions, formulae, and drug doses should be independently verified with primary sources. The publisher shall not be liable for any loss, actions, claims, proceedings, demand, or costs or damages whatsoever or howsoever caused arising directly or indirectly in connection with or arising out of the use of this material. 


\section{ABORIGINAL LIVING}

CONDITIONS AND

RESPONSE PARADIGMS

A March 2000 feature report in The Australian newspaper stated: Since CHIP ${ }^{1}$ started in 1993 more than $\$ 1$ billion has been spent providing essential services such as water, sewerage and roads, and buying and renovating houses for indigenous communities. An estimated 5,000 houses have been built, reducing the overall level of homelessness and overcrowding by 20,000. But the government has been appalled by Northern Territory Government and ATSIC data revealing about 40 per cent of houses owned or administered by indigenous community housing organ-isations require either significant repairs or replacement. If you try an experiment and it fails, you have to try something different,' [ the Minister for Aboriginal Affairs, The Hon. John] Herron says. (Toohey, 2000:26.)

The clear implication within this article is that the government has experimented by allowing Northern Territory (NT) Indigenous communities to administer expensive essential services yet an unacceptable proportion of the houses provided are now dilapidated. It suggests government generosity, in the face of appalling Indigenous failure, along with an alternative approach to essential service management that does not involve Indigenous control of resources. There is an obvious perception that there is a policy problem in managing Aboriginal living conditions.

Clearly the Commonwealth Government recognises 'homelessness and overcrowding' in the NT Aboriginal community as a problem that is not satisfactorily responding to policy solutions. Yet if one is to consider the current policy as experimental and a failure, one must recognise an alternative to that policy. Through considering a case study, this article examines the proposition that recent policy in the NT has involved two quite different approaches. These policies are distinguishable by the degree of authoritarianism as distinct from self determination that is afforded to Aboriginal people in controlling their living conditions.

This study considers a problem in 'Aboriginal living conditions' recently experienced in the Northern Territory, and examines two responses to this problem. The case study begins to illustrate how divergent conceptualisations of Aboriginal living condition problems can develop into inconsistent answers to those problems. It then considers the implications that problem conceptualisation has for intervention and poses questions about the validity of the Commonwealth Government's conceptualisation of Aboriginal living condition problems. Finally, it considers the policy implications

For the purposes of this discussion a 'rational' view of policy is presumed. This holds that governments do not intervene in social conditions on impulse and commonly intervention is something that they avoid unless potential benefits are perceived to be greater than possible costs. The intervention process is assumed to seek the most efficient and effective solution to the perceived problem. However the following case study highlights the potential for competing and conflicting perceptions of a policy problem to lead to different outcomes.

\section{A case study of living conditions}

In early 1998 the rural Town of Katherine in the Northern Territory was recovering from a catastrophic flood. Both Commonwealth and NT Government sources were providing emergency financial assistance for Katherine residents and the NT Government was assisting with the clean up. This was a situation of major dislocation, as many residents were without their usual housing and were sharing, living away from home or living in makeshift accommodation. It was a time of stress, a time of frayed sensitivities and a time when Katherine residents needed the support and assistance that their elected representatives seemed to be very willing to offer.

However this was also the time the NT Environmental Health Authority took action to clear both the 'Wallaby Camp' and the 'Red Gum Camp'. According to the long-term Manager of the Wardaman Aboriginal Corporation, Mick Peirce, Wallaby Camp had for some time been a congregating area and domestic space for around 30 Aboriginal residents, and similarly Red Gum Camp supported 5-10 residents (Peirce 1999). The 'clearance' removed from these camps rubbish, all infrastructure, and the 'swags' and personal effects of residents. These were collected and dumped (Campbell 1999). The sites were graded, furrowed and posted with 'no-camping' signage. Though there had been a widely represented community group working on the issue of these camps, there was scant outcry except from Aboriginal groups after this action was taken (Peirce 1999).

A brief examination of this recent 
case-study highlights contrasting perspectives of an 'Aboriginal living condition problem' and provides insight into the potential for contrasting political pressures to lead to different policy approaches.

\section{A Wardaman account of the problem}

In 1994 the then Federal Health Minister, Senator Graham Richardson, visited Katherine and described the living conditions at the camps as appalling and 'Third World'. In response to considerable media coverage the NT Minister for Lands Housing and Local Government, and Aboriginal Development (The Hon. Steve Hatton) set up the Katherine Aboriginal Living Areas (KALA) Working Party to look into the conditions and to develop cooperative strategies for addressing the issues (Peirce 1999. Hatton 1995).

The KALA began meeting regularly in Katherine and seeking strategic responses to the main problems identified by the group. Shortly after this the Kalano Aboriginal Corporation redeployed some government funds to provide a water supply, a waste removal service and portable toilets at the camps (Campbell 1999).

A consultant was commissioned by the KALA working party to report on the land and accommodation needs of the Aboriginal people in and around Katherine (Peirce 1999). He proposed that living areas be established at Wallaby Camp, at Red Gum Camp and two other sites. According to this report there was an estimated need for 71 houses with an expected need for 45 more by 2004 (Wigley \& Wigley 1995).

A resulting Memorandum of Understanding formalized arrangements for dealing with 'Aboriginal Accommodation and Related Problems', as it was accepted that some Aboriginal residents of the Katherine area had significant alcohol-related behavioural problems. This was a significant issue in the Katherine community. The Memorandum recognized 'That an improved quality of life for all members of the community [was] best achieved through a cooperative approach by all parties concerned' (KTC 1995). This consultative and planned approach strategically dealt with Aboriginal living condition problems through distinct housing and social behaviour strategies (KTC 1995). Thus, the camps were regarded as interim accommodation measures to be improved upon within the intent of the Memorandum of Understanding. Similarly there was to be a separate study and strategic response to behavioural issues.

To the Wardaman Aboriginal Corporation this approach was justified as the camps had been long established on Crown land, and some residents had been in the vicinity of Wallaby Camp for decades. Prior to this, Aboriginal people had always lived in and around the areas giving them some moral right to establish themselves more formally (Peirce 1999). In this light as the Red Gum and Wallaby sites were provided with shelters, toilets and water supplies, this was further evidence of legal sanction for their domestic residence in the Katherine environs. The planned and cooperative strategy was a concession to Aboriginal rights to live 'decently' in the area as it was a concession to other residents rights to 'decent' behaviour in the area.

\section{A government account of the problem}

The negotiations in developing the Memorandum of Understanding between the Mayor of Katherine and representatives of the Katherine Combined Aboriginal Organizations ${ }^{2}$ exposed a divergence in interests between the parties.

Minister Hatton held one perspective of the Katherine Aboriginal living condition problem. He had been concerned about problems in respect to Aboriginal 'camping' in the Katherine vicinity for some years prior to Minister Richardson's visit (Hatton 1999). Similar problems had been experienced in the Tennant Creek and Alice Springs areas. There was a perception that previous actions in establishing Aboriginal Living Areas around Tennant Creek and Alice Springs had led to more Aboriginal people moving into the area and more illegal campers in the vicinity (Hatton 1999). There was also a persistent perception of social behaviour problems in these towns.

The major division between the Wardaman Corporation and government views, as evidenced in minutes of the KALA working party, centered on the issue of offensive behaviours in public. The Katherine Town Council was concerned about potential influxes of illegal campers who would participate in these behaviours and would worsen the problem in Katherine (KTC 1995; Hatton
1999). To the Katherine Town Council, the Wallaby and Red Gum camps were a source of persistent behavioural problems which they had to address (KTC 1995 Hatton 1999). From their perspective, the camps were drinking sites and the campers were a source of offensive behaviour associated with public drunkenness.

As these camping areas were not gazetted for Aboriginal living, they were not bona fide Aboriginal Communities and therefore the 'campers' had no right to be living there. From this perspective the residents were illegal campers who chose this lifestyle rather than the strictures of Aboriginal laws in Aboriginal Communities (Hatton 1999). Other accommodation was available to them through Aboriginal Hostels Limited and the Department of Housing if desired and if they were prepared for a brief period on a waiting list. Yet these apparent lifestyle problems seemed to be caused by deliberate choice and the Minister, as the legal owner of the public space, had every right to move the campers out and clear the land (Dalrymple 1996).

As the KALA working party's commissioned reports were firmly in favour of establishing the camps (in addition to other camps) as bona fide Aboriginal Communities they were, in the Council's view, rewarding the behaviour that it opposed. Its concern was that this would firmly establish social problems in these locations.

Response strategies were being negotiated through the Memorandum of Understanding, with the Katherine Town Council cautiously moving towards acceptance of a compromise that dealt with perceived social problems. Minutes of the KALA indicate this may have been a difficult process considering the differing views, the strength of the views and the weight of Katherine Combined Aboriginal Organisations' (KCAO) representatives.

In 1996 there was a Ministerial reshuffle in the NT Cabinet: Minister Hatton was demoted and the Member of the Legislative Assembly for Katherine, The Hon. Mike Reed, was appointed as the Minister responsible for Lands Planning and Environment (Peirce 1999). He had a different approach to the KALA working party. After a few further meetings the committee dissembled (Peirce 1999; Reed 1999). It was later replaced with the Katherine Antisocial Behaviour Committee which had no Aboriginal representation and much closer Ministerial control over the 
composition and proceedings (Peirce 1999). Commitment to the Memorandum of Understanding waned with the collapse of the KALA working party. The bipartisan approach to the issue of Aboriginal living areas in Katherine floundered.

Then in 1998, after the flood the camps were razed. Eviction had been seen as necessary because of the persistent behavioural problems and health concerns. A new 'drinking area' was established about 12 months later to bring the committee 'another step closer to solving the problems [that] were faced ... daily in [Katherine's] streets'.

\section{Closing statements}

Evidence indicates that the previous residents of Wallaby and Red Gum Camps still live in and around Katherine (Campbell 1999, Peirce 1999). Long term Katherine resident and Wardaman associate, Bill Harney, believes that since the 'clearance' one Wallaby Camp family was offered Housing Commission accommodation and was later evicted for allowing other family members to overcrowd the house (Harney 1999). Others are living near the creek, in the bush (Harney 1999). The drinking area has failed to attract drinkers, and the problem behaviours that were evident in Katherine are still pressingly evident.

As a response to behavioural problems in the Katherine community it is clear the strategic actions were ineffective. The Katherine Combined Aboriginal Organisations (KCAO) component of the KALA working party accepted that problem behaviours existed in Katherine, but saw them as social problems which related to alcohol abuse and as such should be dealt with through 'Living With Alcohol' and such programs in the community. They were not convinced that the campers were any more responsible for offensive behaviour than were other Katherine residents (Peirce 1999). Campbell has stated that the behavioural and camping issues are not associated and that the residents of these camps were not problematic drinkers (Campbell 1999).

The residents were permanently moved away from Red Gum and Wallaby Camps without compensation or alternative arrangements. The government initially consulted widely, developed a planned and logical strategy at some cost and then without evaluating this strategy terminated its development in preference to a partisan dispersal strategy. As there had been, at the time of writing, no official evaluation of the relative success of the dispersal strategy and no reestablishment of the KALA, then it must be assumed that the policy response was about non-Aboriginal control of Aboriginal behaviour.

The analysis so far indicates that the government felt the need to act in solving the problems that were faced daily by some constituents (the non-Aboriginal residents of Katherine) even though the action worsened the intended target (quality of life) problems of other constituents (the Aboriginal campers).

This poses the question: what causes a government to have two alternate approaches to intervening in problems related to Aboriginal living conditions? Further, is there confusion in the perceived basis of the Aboriginal living conditions problem, that incorporates perceptions of accommodation expectations, behaviour expectations and residential location expectations.

\section{A problem for policy}

Simplistically there would appear in the Katherine case study to be policy approaches that

(a) sought to help Aboriginal people deal with perceived living condition problems through consultative interventions, and

(b) sought to control Aboriginal people and eliminate perceived problems that their behaviours created.

These alternative approaches are favoured according to the dominating perception of who deserves to have their need attended to. These became competing rather than complementary positions.

In considering Aboriginal affairs policy since 1967, Jennett (1990:246) considers that 'opposing interests occur at varying levels ... [from] the racial divide ... [to]... the rich/poor dichotomy' with the broader community representing their own interests as embodying the national interest. Clearly there is an informed perception that Aboriginal interests are commonly rejected and redefined in favour of broad community interests.

'The fact is that Aboriginal interests conflict with many more powerful ones and, when these are at issue, it is the Aboriginal interests which are generally compromised' (Jennett 1990). The NT Government acted as an instrument of more-powerful interests dominating less- powerful ones. Such a position seems to understate the initial effort put into the consultative approach to Aboriginal living conditions in Katherine. Thus the policies that have been developed in support of Aboriginal chosen lifestyles argue for a broader analysis.

In the Katherine case study the perceived causes of the problem are represented by two interest groups. The Wardaman view, representing the KCOA, was that there is insufficient appropriate accommodation for a growing and diverse Aboriginal population in the Katherine region (Peirce 1999). Behavioural issues were acknowledged, and were to be addressed as a symptom of inappropriate living conditions, and consequent social problems. This perspective was being incorporated into policy while Hatton was the responsible Minister. Hatton, however, also articulated an alternate view that he considered was pervasive in the broad (Katherine) community. This position held that Aboriginal people were flooding into the towns because of a desire to drink alcohol and break free of the strictures of tribal law (Hatton 1999). When in towns these people refused to adopt the expected mores of the broader community pertaining to habitation of appropriate housing, behaviour in public and standards of cleanliness (Hatton 1999). Within this view are resident assumptions about accepted behaviour in towns, the options available to Aboriginal campers and who is responsible for the problem behaviours.

The Wardaman view and the Katherine residents' view of the problem differ in perceived levels of Aboriginal control over the Aboriginal living condition problem and in the perception of how much control they should be afforded in the policy response. The above perceptions of the problem shall be referred to as Problem Perception (1) and Problem Perception (2) referring to Peirce's view of the problem and Hatton's view of the (residents' perception of the) problem, respectively.

Problem Perception ( 1 ) is that the problems are logical social consequences of a lack of appropriate living conditions (areas, housing and services) for Aboriginal people. From this perspective there are today greatly limited choices for Aboriginal people. They are much less able to move about than they traditionally would have been as a result of land tenure and zoning issues. They are also likely to live in overcrowded houses, to live in 
settlements where there are social problems, and to have insufficient access to employment or recreation (Peirce 1999). The situation of reduced choice that they experience requires some form of social correction. The preferred response therefore is a planned one dependent on the needs of the people and increasing their capacity to respond to these problems.

The alternate 'residents' Problem Perception (2) is that deliberate Aboriginal misbehaviour is creating the living condition problems. From this perspective they are not choosing to behave appropriately while in town, and are choosing to live in town so that they can behave in this way. Therefore, logically, the Aboriginal offenders should be controlled by the appropriate government agencies, such as local authorities, police, or welfare workers. From this perspective Aboriginal people have more than adequate choice and are deliberately picking the wrong choices. From a non-Aboriginal value base, they could be seen as abusing privileges that society had afforded them and so deserve a reduction in their choices.

Alternate understandings of the source of the above problem define radically different solutions. In the Katherine case study, the NT Government under Minister Hatton, seemed to be amenable to some of the Peirce agenda but cautious about the preponderance of Problem Perception (2) in the broader community. The task of appeasing both interest groups is difficult when they have conflicting interpretations of the problem and opposing positions for its solution. If more options were provided for Aboriginal people in Katherine, then proponents of Perception (2) would feel that Aboriginal people were being rewarded for bad behaviour. If a punitive approach were applied, Hatton was aware that the problem would persist. Thus he developed a consultative approach that required consensus among the representatives of the opposing interest groups and acceptance of the need for additional time and resources by the broad community.

Minister Reed is also the local Member of the Legislative Assembly for Katherine. $\mathrm{He}$ is much closer to any ill-will in the predominantly non-Aboriginal Katherine electorate. There is much for him to lose in making a policy decision that disaffects the non-Aboriginal population. The policy problem is then in reducing community exposure to offensive behaviour, vagrancy (influxes of Aboriginal campers), health problems reduced community amenity resulting from rubbish, and perceived loss of community control. Reed's response to the problems could be seen to comprise a need for healthy Aboriginal housing away from Katherine residents, for control of drinking, for control of alcohol associated behaviour problems, and for health services. This approach could be applied more quickly, more cheaply and in a way which was easily explained to the broad community in terms of popular values.

\section{Wider Aboriginal living condition perspectives}

Clearly perspectives of the problem are important determinants of government action. In Peirce's view the Katherine Aboriginal living area issue arose as a result of Minister Richardson's scrutiny and consequent media comment about the poor conditions under which Aboriginal people were living at Wallaby and Red Gum Camps. In official media releases NT Ministers Hatton, Manzie and Reed have all described Aboriginal living conditions ${ }^{3}$ and commented on the need for action. These conditions have even been described as 'appalling' problems that require in excess of $\$$ lbillion from the Commonwealth Government to resolve (Hatton 1995)

Certainly the living conditions themselves are significant enough issues to be presented in the public arena. There is a considerable body of literature about government intervention into Town Camps (Memmott 1988, 1991 , 1996, Ross 1999). Further there is general acceptance that considerable action has been taken intervening in Aboriginal living conditions in Australia, and Heppel and Memmott have documented government intervention into indigenous living conditions over many years (Heppell 1975, Memmott 1988, 1991, 1996).

It must be assumed that the significance of Aboriginal living conditions (and Hatton's actions) have demonstrated that there is a government perspective that this problem deserves a socially benign solution rather than mere punitive control. Clearly there is tension between the desire to control and the desire to help. The current expenditure on essential services and Herron's press statement indicate extensive political commitment to improvement of Aboriginal living conditions in settlements. Thus, the case study poses the questions: If this is so significant an issue, why, in nearly forty years, are governments still strategically unsure how to act, why are objectives not clarified, why are strategic interventions not implemented, and why is the problem not solved?

\section{Historical background}

To answer these questions about the apparent failure of policy to service Aboriginal living conditions, it is necessary to consider the history of interest in these conditions. There have been various depictions of Aboriginal living conditions over time. An early appeal was made in December 1969, by W.D. Scott and Co, to raise the living standards and self sufficiency of Aborigines in South Australia (including the NT)(Scott 1969:1-4). The way this was articulated supports the perception that the poverty of these conditions was self-evident. W.D. Scott \& Co. reported again in 1973 on the housing needs of Aboriginal people (Scott 1973). They argued for considerable public housing of appropriate style for Aboriginal people.

In 1975, Henderson's Commission of Inquiry into Poverty in Australia reported:

The state of housing is probably one of the more obvious signs of poverty among Aboriginals. Many Aboriginal families live in substandard and overcrowded accommodation. .... In the rural areas of most States there are many Aboriginal people living in humpies and other improvised dwellings (Henderson 1975:268).

Henderson's nine recommendations can be grouped into three regarding self determination/service delivery, one for income support, two for employment training, and three for housing assistance (1975:268). There seems to be a perception that substandard living conditions are obvious in Aboriginal lifestyles and that this is evidenced in humpies and substandard housing

O'Connell described the public image of Aboriginal living as one

of poverty stricken people camped at the edge of a country town or on the barren back lot of some government reserve or settlement, with no shelter but a wrecked sedan or a ramshackle shed made of rusty sheet metal and a few scraps of cast-off tarpaulin or blanket (O'Connell 1975:97). 
A picture of people living in poverty, and of unhealthy, deficient housing seemed to develop through the 1970s as the dominant perception of Aboriginal living conditions. Memmott has described how Aboriginal activities in response to their own living-condition requirements have been ignored or devalued in favour of an ethnocentric imperative to improve the housing of Aboriginal people (Memmott 1996). Memmott described how the image of the humpy became an image of deficiency against a European standard of desirable housing, or living conditions.

The 'deficit approach' to Aboriginal living conditions has underpinned Aboriginal social (housing) policy and the current Commonwealth Government's National Aboriginal Health Strategy 4 (NAHS). The NAHS has sought to strategically respond to those substandard living conditions that cause poor health. As part of that charter, the National Aboriginal Health Strategy sought to comprehensively document indicators that would assist in understanding the living conditions of Aboriginal people throughout Australia. This was a new, primary health approach to considering and officially responding to Aboriginal living conditions. It examined the living conditions of Aboriginal people as deficits against ideals in achieving good health outcomes. It was ascertained that a major deficit existed in the standard of healthy and appropriate housing, and it became a priority of the NAHS to increase the stock of quality housing on Aboriginal communities. The Commonwealth Government's contemporary measure of success in improving health and living conditions is presented as the reduction over twenty years from 20 percent to 3 percent of Aboriginal Australians residing in make-shift dwellings (Ruddock 1999).

The mainstream approach to housing dominates and Aboriginal modifications to their living conditions are generally evaluated as substandard and unhealthy. This is supported by Bostock in finding widespread misrepresentation of Aboriginal and Torres Strait Islander people in the media. He considers that their:

depiction has been mostly negative with stereotypic representations of Aboriginal people... [T] hey have been presented as either threats to society or victims of it (Bostock 2001:1).

In this context their self-housing agenda is interpreted as an example of housing based victimisation. Further,
Sanders has clearly articulated how the bureaucratic (sectoral) agenda dominated the housing agenda and developed through the 1980 s a statistical articulation of this housing deficit as a quantitative interpretation of Aboriginal living condition problems (Sanders 1990).

An alternative agenda, based on a deeper understanding of Aboriginal requirements, was eclipsed by more easily expressed 'scientific' measurements (Sanders 1990). NT requests (above) for \$1billion to meet the backlog of housing is testimony to the widespread acceptance that Aboriginal living conditions are deficient and that a quantitative approach to estimating housing requirements is to some extent beneficial.

To inform government about the living conditions of Aboriginal people in the NT the Northern Territory Parliamentary Library has tried to compile all articles on this issue since $1990^{5}$. The articles predominantly present Aboriginal living conditions as problems in health, housing, services (especially sewerage), community cleanliness and nutrition. Some articles appear to purposefully depict damaged, run-down structures, dirty facilities and strewn rubbish as a reflection of poor conditions experienced by Aboriginal people. A few articles depict a positive image of Aboriginal people; however on several occasions this followed a complaint in a previous letter to the newspaper about negative depictions of Aboriginal people. Figure 1 displays a qualitative assessment by this author of the positive or negative nature of the presentation of these issues in the NT Parliamentary Library dossier. These data have been numerated as positive or negative occurrences of each of the eight issue categories. In the absence of other systematic available information, this picture may be perceived to present to government a negative dominant perception of these living conditions. The community and government are likely to perceive that Aboriginal people have significant need of health and housing intervention. This picture is supplemented by a wealth of survey research and academic material that has measured a need for Aboriginal housing. Such a wealth of 'scientific fact' has favoured housing intervention of some sort or another into Aboriginal living conditions.

Against the above perceptions, choosing to camp rather than to occupy a hostel, community or commission house would seem a perverse choice to proponents of government policy. They see such Aboriginal living conditions as unhealthy and sub-standard. Thus choosing to live in an unhealthy and substandard camp is tantamount to rejecting accepted standards of European behaviour. This was negatively perceived by some in Katherine but was seen by Minister Richardson as evidence of deprivation and homelessness in Aboriginal settlements. This either required Aboriginal relocation or social expenditure on infrastructure, depending on the view held.

An alternate perspective has, however, existed at least for the last 30 years. Hamilton (1972) discussed aspects of

\section{FIGURE I: LUVING CONDITION REPRESENTATIONS (ABORIGIHAL MEDIA CUPPINGS)}

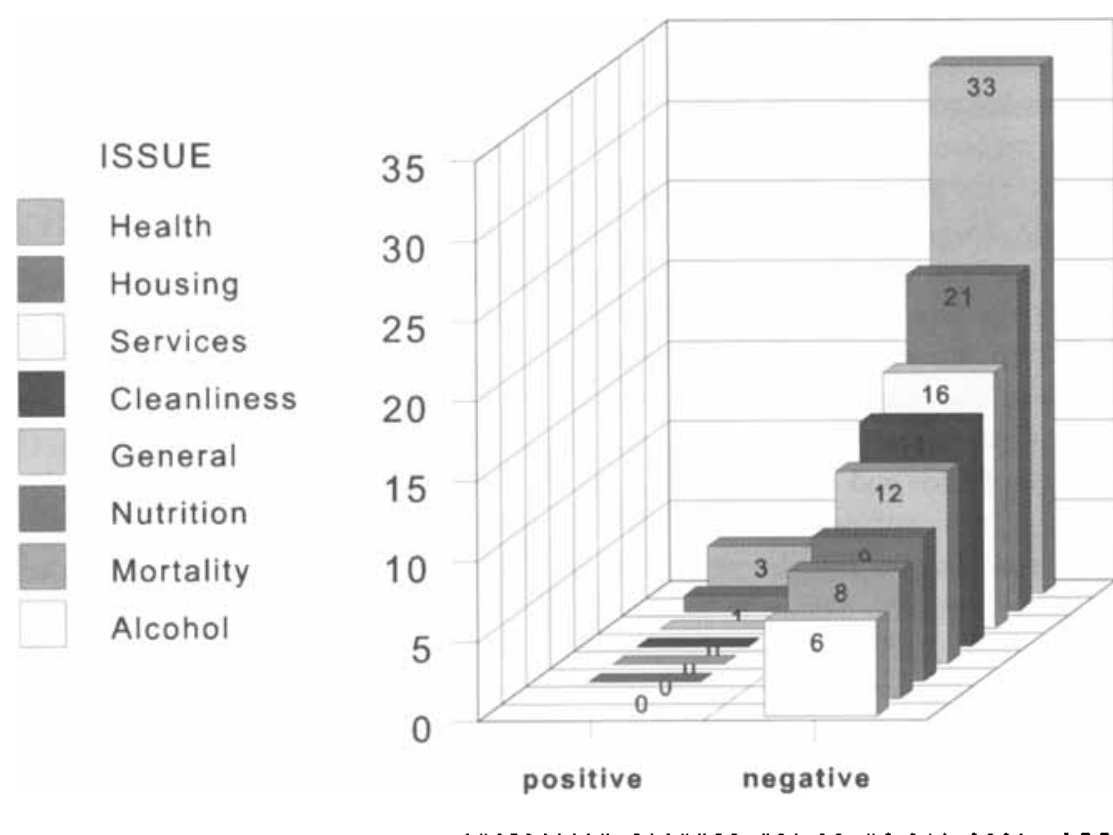

AUSTRALIAN PLANMER YOL $38 \times 03 / 42001$ 
Aboriginal living requirements in his early work on social behaviour and the built environment in relation to groups living in the Evicaard Range land. This work describes a complex and functional system of social integration with purpose built and natural environmental conditions. He recommends caution in any intervention into this system. He considered that;

If the conditions and practices in

Malutjara society are viewed as 'social indicators' and applied to the (physiological, environmental, ecological, psychological, and social needs of Aboriginal people) it will be found, that the 'quality of life' in this society is at a high level (Hamilton 1973:3).

Traditional camps may have provided Aboriginal people with a high quality of life. W.D. Scott's 1969 and 1974 work emphasised the inappropriateness of standard housing for some Aboriginal people and stated that these people were able to meet their own housing needs. Memmott over a period of time has argued convincingly that Aboriginal people in humpies, makeshift housing and tin sheds have had, at times, a superior quality of life to those who had been subject to inadequately designed housing through housing programs (Memmott 1999). The above case study indicates that many Aboriginal people chose camping over the provided housing and hostel accommodation that was available and one family had been living for 20 years in and around Katherine without formal housing (Peirce 1999).

It can be argued that at certain times camping provides a superior quality of life to inappropriate accommodation, depending partly on the definition of 'quality of life' that is applied. Recent work by Senior indicates that, in terms of the priorities of some Aboriginal people who reside within the confines of Darwin, housing is of low importance (Senior 1999). This is not to say that Aboriginal people do not want houses. What it suggests is a more complex picture in which the provision of physical housing is but one element within a complex set of needs that may vary in their priorities and in the way they are acted upon. For example Peirce and Campbell concurred that a perception of appropriate accommodation for the residents of Wallaby Camp was a place surrounded by relatives aligned towards their country and distant from certain incompatible clan groups. Though appropriate housing was seen as important, the physical qualities of the shelter seemed to be less important than the above siting attributes.

In the Katherine study, the concern for Aboriginal living-condition requirements that was precipitated by Richardson was combined with behavioural issues that related to non-Aboriginal expectations of Aboriginal people in the town. This corresponds with the view that the interest of non-Aboriginal people tend to dominate the perception of Aboriginal requirements.

Similarly there has been on the part of government an expectation that Aboriginal people should live under conditions that align with the broad community's perception of appropriate living conditions. This has been manifest in defining the Aboriginal lifestyle needs of Aboriginal people as 'housing needs' The long-standing agenda to improve 'appalling' living conditions of Aboriginal people has justified housing provision in settlements.

This accords with Jennett's view that the broader community represent their own interests as embodying the national interest (Jennett 1990) and that Aboriginal interests are compromised in the byplay. That which one person derides, another may prefer. This depends on how one perceives his/her interests. Thus the policy problem similarly may be perceived by some Aboriginal people as a desire to impose appalling conditions on them through housing policy. Under such conditions it is not likely to achieve success for all Aboriginal people.

\section{Living or housing occupancy}

From the perspective of the Katherine Aboriginal Living Areas working party the interests of the campers would have been better served by addressing: 1) housing and living area needs, and 2) social behaviour strategies. In the first areas of interest, Aboriginal living requirements were seen as a need for 71 houses, in socially appropriate sites. That is, the sites were selected for their familiarity to the Aboriginal people, proximity to clan-relations and distance from incompatible clan groups (Peirce 1999, Wigley 1995). The fact that an appropriate layout is factored into this plan may be a reflection of the experience of the settlement planning consultant (J Wigley), but it was also a cause of the problems that the NT Government had with the plan. The government accepted the need for housing but the siting was not acceptable and was rejected. This may be a reflection that a conceptually deep understanding of Aboriginal living condition requirements is not yet demonstrable in 'scientific fact' and yet Aboriginal living needs are evidently in conflict with the living condition requirements of other parties. In the absence of a depth of understanding of living requirements, Aboriginal living needs are easily equated to housing requirements (Sanders 1990).

This picture could be developed further by examining social statistics from the National Aboriginal Health Strategy reports, the Report of the Social Justice Commissioner or the Australian Bureau of Statistics (National Aboriginal Health $\&$ Equal Opportunities Commission 1996; ABS 1999). All these reports emphasise a pressing need for housing for Aboriginal people.

One of the most recognised sources of information about Aboriginal living conditions would have to be the National Aboriginal and Torres Strait Islander Survey (ABS 1999). This document is an officially chartered investigation of Aboriginal issues. It addresses this issue, in indicating that Aboriginal living conditions are predominately enumerated by statistics about housing densities, health indicators, access to services and physical facilities. Quantities of 'healthy housing' full of 'health hardware' are perceived to service Aboriginal living condition needs, yet such hardware can be most unhealthy if it disempowers the residents and they use it inappropriately (Lavarach 1999).

The Aboriginal perception of Aboriginal living conditions is not present or is largely absent from these analyses of their requirements. Senior's work tends to indicate that in terms of priorities for their quality of life, housing is of low importance to the NT Aboriginal people with whom she consulted (Senior 1999). Peirce (1999) and Campbell (1999) concurred that the perception of appropriate accommodation for the residents of Wallaby Camp was a place surrounded by relatives aligned towards their country and distant from certain incompatible clan groups. Though appropriate housing was seen as important, the physical qualities of the shelter seemed to be less important than the above conditions. Senior's findings support the position that Aboriginal priorities emphasise family, culture, self-pride, health and control (empowerment) over other factors. 


\section{Conclusion}

This article identifies two alternate perceptions of the problem of Aboriginal living conditions in the Northern Territory. The discussion has however been dominated by the negative perception of Aboriginal living conditions that are incorporated in paradigms that underpin both perspectives. The Problem Perception (1) held that Aboriginal living conditions were appalling and required further financial intervention, whereas Problem Perception (2) viewed Aboriginal living conditions as appalling by choice. Both policy approaches were thus ethnocentric. This is because there seems to be scant information about actual Aboriginal conceptualisation of 'Aboriginal living conditions'.

The term 'Aboriginal living conditions' is defined in housing and social behaviour terms. This draws together quite different pictures depending on the point of reference. The dominant referent currently presents Aboriginal living conditions as requiring healthy housing provided according to the dictates of government. Yet case evidence indicates that poor success may result from imposed solutions to Aboriginal living condition needs. This may be presented however as the fault of Aboriginal people who have ill-used their control over the processes.

The picture forming is that government is influenced by scant information about Aboriginal living preferences, and is antipathetic to the idea of Aboriginal control over the process. By contrast considerable regard is held for a perceived need for large quantities of 'healthy' housing on designated Aboriginal communities. Although the promotion of Aboriginal health is laudable in general humanitarian terms the ethnocentricity of the concept construct may have a substantial impact on depreciating Aboriginal perceptions of their living condition needs. Certainly Minister Herron was speaking of reducing rather than increasing Aboriginal participation in provision. In light of the evident historical domination of Aboriginal perceptions of their need, in light of the lack of Aboriginal participation in setting the Aboriginal living condition agenda and in light of evident moves away from Aboriginal control, we need to reexamine the underpinnings of housing and Aboriginal living condition policy.

The case study shows that the two approaches can produce quite different policy outcomes. There is a clear need to locate Aboriginal housing within the far wider context of overall living conditions and to positively reconsider current approaches to Aboriginal life choices.

\section{NOTES}

${ }^{1}$ The Community Housing and Infrastructure Program 2 Comprising the Aboriginal organisations attending the KALA working party

3 That Minister Hatton convened a working party and personally attended meetings some 340 kilometres from Darwin, demonstrates some commitment to responding to Aboriginal living conditions in the area.

4 The National Aboriginal Health Strategy 1989 incorporates this Strategy which is focussed by CHIP policy.

${ }^{5}$ Logically most articles are from NT newspapers

\section{REFERENCES}

Australian Bureau of Statistics (1999) The Health and Welfare of Australia's Aboriginal and Torres Strait Islander Peoples Commonwealth of Australia, Canberra

Bostock, L (1990) The Greater Perspective: a guideline for the production of film and television on Aborigines and Torres Strait Islanders, SBS http://www.abc.net.au/message/propet/mediarep.htm Campbell, R (1999). Personal Communication Discussing Aboriginal Living Areas, 17 September 1999, Kalano Association, Katherine, NT

Human Rights and Equal Opportunity Commission, (1996) Aboriginal and Torres Strait Islander Social Justice Commissioner, Fourth Report 1996, The Commission Canberra

Hamilton, $P$ (1972) Aspects of Interdependence between Aboriginal Social Behaviour and the Built Environment, Aboriginal Data Archive, University of Queensland.

Hamilton, P (1973) Environment and Social Stress in a Traditionally Oriented Aboriginal Society, Cultures in Collision, Twenty Fifth World Mental Health Conference, Sydney

Harney, B (1999) Personal Communication Regarding Aboriginal Living Camping Conditions, 22 October 1999 \& 7 December 1999, at Wardaman, Aboriginal Corporation, Katherine NT

Hatton, S, (1999a) Personal Communication regarding Katherine Aboriginal Living Areas Working Party 21 September 1999, Nightcliff, NT.

Hatton, S. (1999b). Personal Communication regarding Katherine Aboriginal Living Areas Working Party Several Dates in December 1999, Nightcliff, NT.

Henderson, RF (1975) Poverty in Australia Commission of Inquiny into Poverty Commonwealth of Australia, Canberra

Heppell, M (1975) Introduction: Past and Presen Approaches and Future Trends in Aboriginal Housing' in A Black Reality: Aboriginal Camps and Housing in Remote Australia, M. Heppell, Australian Institute of Aboriginal Studies, Canberra

Jennett, C (1990) Chapter 8: Social Policy, in Hawke and Australian Public Policy, C. Jennett \& R. G. Stewart (eds) MacMillan Education Australia, Melbourne

Lavarach, M (1999) Unpublished Paper for The Territory Health Services Department, on Housing and Infrastructure in Amhem Land, Darwin, NT.
Katherine Town Council (1995a) Memorandum of Understanding: Social Behaviour Strategy Katherine, NT, Katherine Town Council \& Katherine Combined Aboriginal Organisations

Katherine Town Council (1995b) Minutes of the Katherine Aboriginal Living Area Working Party, Katherine NT

Memmott, $\mathrm{P}$ (1988) Aboriginal housing: The state of the art (or non-state of the art), Architecture Australia, June: $34-47$

Memmott, P (1991) Humpy, House and Tin Shed: Aboriginal Settlement History on the Darling River, Ian Buchan Fell Research Centre, University of Sydney

Memmott, P (1996) From the Curry to the Weal: Aboriginal Town Camps and Compounds of the Western Back Blocks, Fabrications, 7(August): 1-50

Memmott, P (1999) Customary Camps and Houses of the Tangik Peoples of the Southern Gulf of Carpentaria, in A History of Aboriginal Housing. P Read (ed) Aboriginal Studies Press, Canberra

National Aboriginal Health Strategy Working Party (1989) A National Aboriginal Health Strategy, Department of Community Services and Health. Canberra

O'Connell, JF (1975) A Room to Move: Contemporary Alyawara Settlement Patterns and their Implications for Aboriginal Housing Policy', in A Black Reality: Aboriginal Camps and Housing in Remote Australia, M. Heppell (ed), Australian Institute of Aboriginal Studies, Canberra: 97-120.

Peirce, M. (1999) Discussion of Camp Closures, Wardaman Aboriginal Corporation

Reed, M (1999a) Media Release: Untitled, 20 April 1999, Parliamentary Library, Darwin, NT

Reed, M. (1999:b) Media Release: Government to Proceed Immediately on Drinking Area, 4 May 1999. Parliamentary Library, Darwin, NT

Ross, $\mathrm{H}$ (1999) Lifescape and Lived Experience, in P Read (ed.) A History of Aboriginal Housing, Aboriginal Studies Press, Canberra

Sanders, W (1990) Reconstructing Aboriginal housing policy for remote areas: How much room for manoeuvre? Australian Journal of Public Administration, March, 49(1): 38-50

Scott, WDC (1973) A Report for the Commonwealth Department of Aboriginal Affairs: Housing Needs In the Australian Aboriginal and Torres Strait Islander Populations, Department of Aboriginal Affairs, Adelaide WD Scott \& Co. (1969) Raising the Living Standards and Improving the Self-Sufficiency of Aborigines. A Proposal to Define and Plan a Pilot Project, WD Scott $\&$ Co, 1-15

Senior, KA (1999) Potential Domains of Quality of Life in Two Urban Aboriginal Communities, North Australian Research Unit (ANU) Seminar, Darwin

Toohey, P (2000) Body Blows, The Australian Newspaper, March 4-5: 26

Wigley, J (1995) Proposed Aboriginal Living Areas: Katherine. Report to the Katherine Aboriginal Living Areas Working Party on The Aboriginal Residential Land and Accommodation Needs in Katherine NT, J \& B Wigley, Katherine NT

Wigley, J \& Wigley, B (1995) Social Determinants on Physical Planning: Aboriginal Urban Living Areas, J \& $B$ Wigley, Katherine NT 